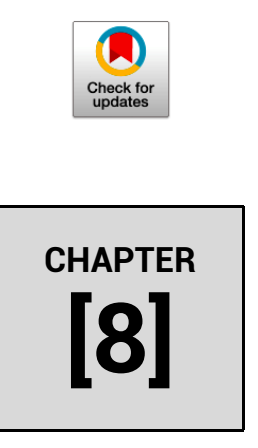

In: Environmental Degradation: Causes and Remediation Strategies

DOI: 10.26832/aesa-2020-edcrs-08

\title{
Current status of water pollution by integrated industrial hubs (IIHs) in India
}

\author{
Vinod Kumar, Piyush Kumar*, \\ Jogendra Singh and Pankaj Kumar
}

Agro-ecology and Pollution Research Laboratory, Department of Zoology and Environmental Science, Gurukula Kangri Vishwavidyalaya, Haridwar-249404 (Uttarakhand), India This chapter reveals the issues of industrialization and its causes and consequences to the environment in total and water in particular. Environmental pollution is a worldwide problem, now receiving worldwide attention. The majority of the solid wastes and wastewaters are released into the soil and water bodies. Fundamental contributors of the surface and groundwater contamination are the results of different manufacturing units, for example, textile, metal, dying chemicals, pesticides, cement, petrochemical, fertilizers, energy, sugar processing, construction, leather, steel, engineering, food processing, mining and others. Water and human health are correlated wherein one affects the other, and the magnitude of the problem is such that its solution invites an integrated approach. Thus, proper treatment and disposal of IIH wastewater should be done to mitigate its environmental impacts. Therefore, this book chapter deals with the characteristics and potential effects of integrated industrial hubs (IIHs) on surface and groundwater quality in India. The information provided suggests implementing effective measures to mitigate their wastewater disposal impacts. 


\section{Introduction}

Water is important for all life forms and comprising up 50-97\% of the mass of all plants and animals and about $70 \%$ of the human body (Allan, 1995). Additionally, water is a fundamental asset for horticulture, manufacturing, transportation and numerous other human exercises. In spite of its significance, water is the most ineffectively managed resource on the planet (Chutter, 1998). The accessibility and nature of water have consistently assumed a significant role in deciding the quality of life. Water quality is firmly connected to water use and to the condition of commercial growth (Chennakrishnan et al., 2008). Ground and surface waters can be polluted by numerous sources. In urban regions, the indiscreet transfer of industrial discharges and different wastes may contribute enormously to the low quality of water (Mathuthu et al., 1997). The vast majority of the water bodies in the regions of the developing world are the endpoints of effluents released from industries. The changes in the nutrient concentrations of water may have prompt harmful impacts on the humans and other forms of life. Most substantial metals in water streams are usually connected with manufacturing discharges and practically heavy metals in industrial wastes have aggregate poisons to aquatic life (Mdamo, 2001). The physico-chemical factors of a water body not just reveal the kind and variety of aquatic biota yet, in addition, the water quality and contamination (Birley and Lock, 1999). Industries are the chief sources of pollution in all environments. Based on the kind of industry, many levels of pollutants can be discharged into the environment directly or indirectly through public sewer lines (Kumar et al., 2018; Kumar et al., 2019a).

Integrated industrial hubs (IIHs) are established to attain the demand of the growing people in the country. The introduction of manufacturing units at one side produces useful products but at the same time, it generates unwanted wastes in solid, liquid or gaseous form that is responsible for the creation of hazards, contamination and losses of energy. The majority of the solid wastes and wastewaters are released into the soil and water bodies. Fundamental contributors of the surface and groundwater contamination are the results of different manufacturing units, for example, textile, metal, dying chemicals, pesticides, cement, petrochemical, fertilizers, energy, and power, sugar processing, construction, leather, steel, engineering, food processing, mining and others (Mdamo, 2001). Therefore, the release of manufacturing wastes, municipal sewage, farm and urban trashes carried by sanitation and canals to streams worsen and increase water contamination. The major problem begins when elevated levels of contaminants in stream water causes an expansion in biological oxygen demand (BOD), chemical oxygen demand (COD), total suspended solids (TSS), total dissolved solids (TDS), and other toxic contents of heavy metals such as $\mathrm{Cr}, \mathrm{Cd}, \mathrm{Ni}$ and $\mathrm{Pb}$ with fecal coliform and thus make such water inappropriate for drinking, irrigation and aquatic life. Chillers and Henrik (1996) has been reported that $60 \%$ of the 
population in developing nations has no access to unadulterated drinking water. In India, both surface and groundwater assets are under pressure. One of the causes for this is the considerable increment in the quantity of grossly polluting industries (GPI). It is estimated that from 2011 to 2018 , nearly $11 \%$ of these enterprises keep on ridiculing pollution control standards in the nation; about half of these are in Uttar Pradesh, India (Pandey, 2019).

Numerous individuals in developing countries of the world still depend on untreated surface water as their basic source of local water supply. Therefore, this issue is worsened in rural regions. Besides this, surface water is progressively under excessive worry because of population explosion and expanded industrialization. It happens due to the availability of surface water settles on them the best decision for wastewater release. Wastewater from IIHs which involves microbes, heavy metals, radionuclides, nutrients, pharmaceutical, and personal use items all discover their approach to surface water resources making permanent damage to the aquatic biological system and to people like the aesthetic value of such water is undermined. These contaminants decrease the quality of useable water, rise the charge of cleansing it, pollute aquatic resources, and disturb food supplies (Edokpayi et al., 2014). Besides this, the lowering in ecological quality is the major sign of environmental degradation (Agarwal, 2005; Georgy, 2011). Environmental laws have been established by the legislature and implemented through its regulatory structures worldwide (Faure, 1995).

Therefore, this book chapter deals with the characteristics and potential effects of integrated industrial hubs (IIHs) on the surface and groundwater quality in India. The information provided suggests implementing effective measures to mitigate their wastewater disposal impacts.

\section{Characters of effluent generated from IIHs in India}

The industrial effluents comprise both inorganic and organic pollutants. The major problem of IIHs began with its small area and inefficient sewer system. Indeed, even today most of the industries don't have appropriate wastewater treatment plants or enough capacity to treat wastewater therefore, they discharge industrial effluents in unlined channels and streams. As a result, the highly colored and toxic effluents join the nearby water bodies which degrade surface as well as groundwater quality. The nature of IIH effluent may not be the same throughout the year. It depends on the type of operating industries within the cluster (Figure 1). The major characteristics of effluent generated from IIHs are provided below:

\section{Physical characteristics}

The key physical characteristics of IIH wastewater are:

Solid contents: The total solids in wastewater comprise of the insoluble or suspended solids and 


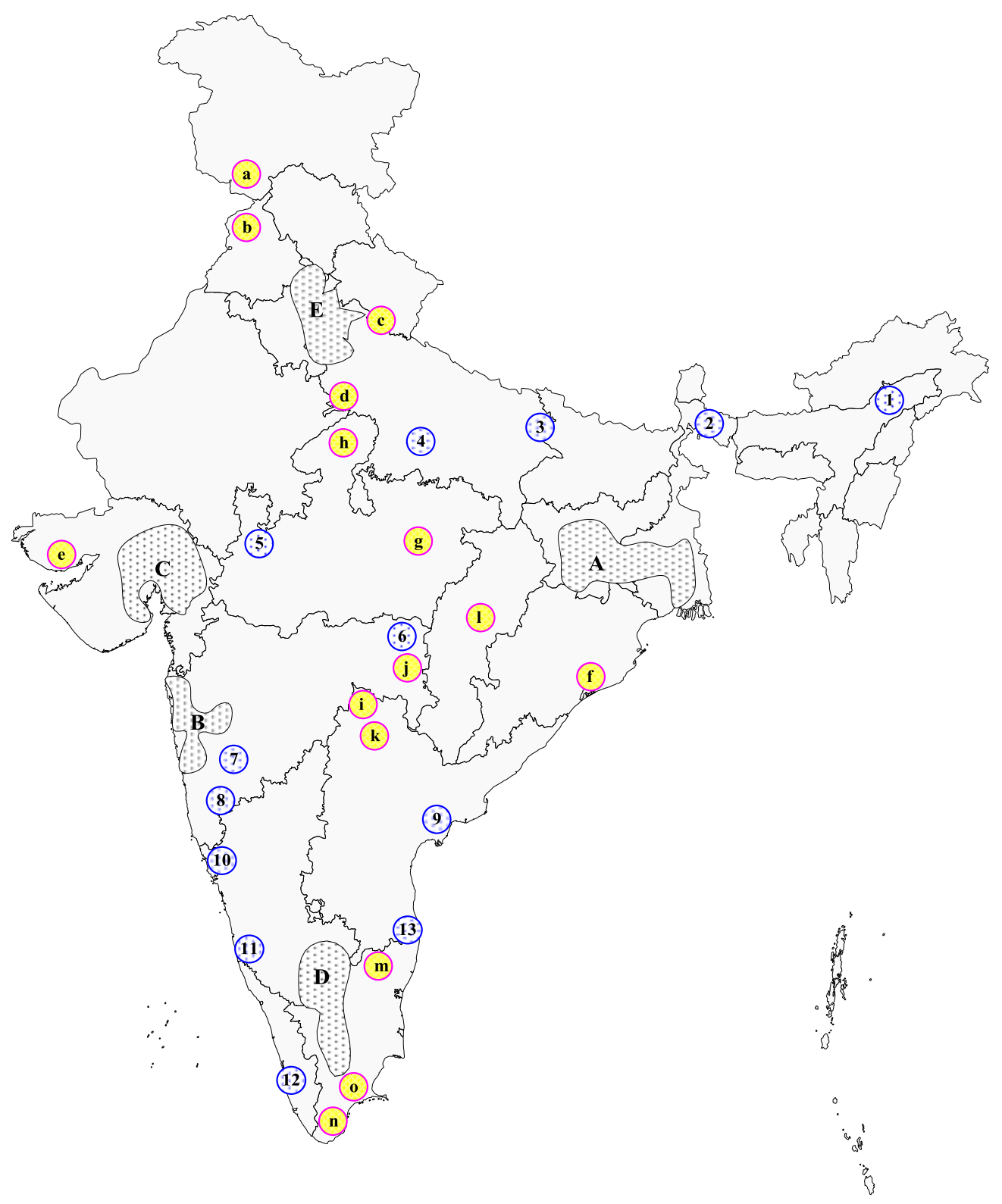

Figure 1. Major industrial hubs of India (a-o: minor hubs; A-E: major hubs; 1-13: manufacturing districts; Source: http://www.geographynotes.com/industries/6-major-industrial-clustersregions-of-india/1058) 
the solvent mixes from different types of industries. The suspended solids content is found by drying and evaluating the remains displaced by the separating of the example. At the point when this residue is burned off the unstable or volatile solids are burnt off. Volatile solids are supposed to be organic matter, while some organic matter won't consume and some inorganic salts separate at high temperatures. The organic matter contains primarily carbohydrates, proteins and fats (Munter, 2003; Kumar et al., 2019b).

Color: Color of IIH effluent is a qualitative character that can be used to measure the overall state of wastewater. Light brownish colored wastewater is generally less than 6 hours old, though wastewaters that have suffered from a degree of decomposition or that have been in the collection unit for a while, a medium grey color is characteristic of that wastewater. The wastewater which is typically poisoned, having undergone wide microbial decomposition under anaerobic circumstances, lastly, the color is dark grey or black (Munter, 2003). The darkening of wastewater is frequently because of the formation of various sulfides, mainly, ferrous sulfide. This happens when hydrogen sulfide generated under anaerobic conditions combines with divalent metal, like iron, which may be present.

Odor: The odor of IIH wastewater is typically aggressive. Various other compounds like skatol, indol, mercaptan and cadaverine formed during anaerobic situations or present in the wastewater of pulp and paper industries (dimethylsulphide, hydrogen sulfide, mercaptan, etc.), may also originate a slightly aggressive odor.

Temperature: Temperature is a significant indicator of water quality with concerns about the survival of water organisms. The temperature of IIH effluent is usually higher than that of the water supply due to warm civic water has been added. The wastewater temperature depends on the procedure of manufacture in the industries.

\section{Chemical characteristics}

Inorganic chemicals: The major inorganic chemicals present in IIH effluents include nitrogen, nitrates, nitrites, phosphorus, and inorganic phosphorus. Nitrogen and phosphorus are significant because these two nutrients are accountable for the growth and development of water plants. Other tests such as sulfate, chloride alkalinity and $\mathrm{pH}$, are achieved to measure the suitability of re-consuming treated wastewater and in supervisory the several treatment procedures. Trace elements, which comprise some heavy metals, are not measured regularly. All living beings need different quantities of some trace elements, such as copper, iron, cobalt and zinc for appropriate growth. Heavy metals can also impose poisonous effects; consequently, measurements of the amounts of heavy metals are particularly significant where, the further use of treated effluent or sludge is to be assessed (Munter, 2003).

Organic chemicals: The BOD and COD of IIH wastewater may be very high as compared to other 
wastewaters. Throughout the years, various different tests have been discovered to find the organic content of wastewaters. The BOD, COD and TOC tests are gross proportions of organic content and thusly don't reflect the reaction of the wastewater to different sorts of biological treatment technologies It is hence necessary to divide the wastewater into various categories (Munter, 2003).

\section{Water pollution by IIH industries in India}

\section{Chemical industry}

Chemicals industry in India is exceptionally enhanced, covering in excess of 80,000 commercial items. It is extensively ordered into bulk synthetic chemicals, specialty synthetics, petrochemicals, agrochemicals, fertilizers, and polymers. India's closeness to the Middle East, the world's foundation of petrochemicals feedstock, makes for economies of scale. India is a worldwide dye supplier, representing roughly $16 \%$ of the world generation of dyestuff and color intermediates. Chemicals industry in India has been de- authorized excluding for limited dangerous chemicals. The chemical industry in India is projected to touch 304 billion dollars in 2025. India ranks 8th in import and 14th in the export of chemicals (Excluding pharmaceuticals products) worldwide. The demand for chemical items is predicted to grow at around $9 \%$ per year throughout the following 5 years. More than 2 million peoples are employed in the Indian chemical industry. The market size of the Indian chemicals industry in 2017-18 is mounted at 163 billion dollars. With a growth of $4.15 \%$ over $2017-18$, the total manufacture of main chemicals and petrochemicals mounted at 27,847 Metric tons throughout 2018-19. Alkali chemicals occupy the major share in the Indian chemical industry in with around 69\% portion in the total production (Invest India, 2019c). The rundown of chemical wastes can be reached out to a few thousand, among them; the fundamental toxins are alkalies, acids, sulfates, phosphorus, nitrates of metals, fluorine, silica and suspended particles. Any processing plant creating synthetic substances is releasing into our water system of one or more kind of lethal chemicals (For model, phosphate industry produces discarded water containing essential fluorine, phosphorus, silica and a lot of suspended solids).

\section{Textile industries}

In India, the textile industry has strengths across the whole value network from yarn, fiber, fabric to apparel. It is extremely expanded with a varied range of sectors reaching from yields of traditional handloom, wool and silk products, handicrafts to the organized textile industry. The structured textile industry is characterized by the use of capital-intensive technology for bulk production of textile items and comprises weaving, spinning, processing, and apparel manufacturing. The national textiles and apparel industry rose at 140 billion dollars in 2018 
(together with handicrafts) of which 100 billion dollars was nationally consumed though the leftover portion worth 40 billion dollars was shipped to the world market. In India's Growth Domestic Product (GDP), the national textiles industry contributes $2.3 \%$ to and $13 \%$ to the industrial production and $12 \%$ of India's export earnings. In India, the textiles and apparel industry is the second-largest employer in the nation providing employment to 45 million people. It is predictable that this amount will increase to 55 million by 2020 (Invest India, 2019a). One textile plant can utilize as many as 2000 diverse chemicals, from dyes to transfer agents (Khan and Malik, 2014). According to Govindarajalu (2003), the water utilization of an average-sized textile unit (production of $8000 \mathrm{~kg}$ of fabric/day) is nearly 1.6 million liters per day. This type of textile mill can also produce up to $200-350 \mathrm{~m}^{3}$ of wastewater per ton of finished products (Ranganathan et al., 2007), causing in average contamination of $100 \mathrm{~kg}$ chemical oxygen demand (COD) per ton of fabric (Jekel, 1997).

\section{Food-related Industries}

At a cumulative average growth rate (CAGR) of $14.6 \%$, the processed food industry in India is estimated to grow to 543 billion dollars in 2020 from 322 billion dollars in 2016. Food processing occupies a significant linking role for Indian farmers to consumers in the national and international markets. Across the value chain, the Ministry of Food Processing Industries (MoFPI) is putting all hard work to encourage investments. The industry involves roughly 1.85 million individuals in around 39,748 registered divisions with secure assets of 32.75 billion dollars and a collective output of around 158.69 billion dollars. Food processing industries consist of grains industries, sugar industries, edible oils industries, beverage industries and dairy products manufacturing industries (Invest India, 2020). Food-processing industries generate wastes like poultry wastes, dairy wastes, meat, sugar processing wastes, canning etc., all are highly degradable and are oxygen (DO) depleting and water supply damaging in much the same way as per domestic sewage. These industries discharge the organic contaminants high in fats, proteins and pathogens. The dairy plants discharge a high volume of effluent (Ramjeawon, 2000), food processing industries consume large quantities of water and are therefore a nuisance to the environment. Effluents from food processing units have moderate to high biological oxygen demand, high chemical oxygen demand, high suspended and dissolved solids and great nutrient content such as nitrogen, phosphorous, heavy grease and oil. This wastewater is amicable to non-chemical biological treatment including anaerobic management like Hybrid Up-flow Anaerobic Sludge Blanket Reactor (HUASBR) trailed by aerobic treatment.

\section{Paper and pulp Industry}

India's share worldwide in paper demand is progressively increasing as the national requirement 
is growing at a steady pace while requirement in the western countries is shrinking. At a CAGR of $6.4 \%$, the national requirement in India increased from 9.3 million tons in 2008 to 15.3 million tons in 2016. Despite the constant development observed by the industry, the paper utilization in India stands at a slight over $13 \mathrm{~kg}$ per capita which is far lower the international average of $57 \mathrm{~kg}$ and expressively below $200 \mathrm{~kg}$ in North America. According to IPMA's (Indian Paper Mills Association) evaluates, this industry contributes roughly 4,500 crore rupees to the exchequer and gives work to more than 5 lakh individuals crosswise over around 750 paper plants. There are four major segments of the paper industry: printing and writing (PandW), packaging paper and board, specialty papers and others, and newsprint.

The paper production process needs a huge quantity of water for the manufacture processes; therefore it is a water exhaustive process. The basic raw materials are utilized for the manufacturing processes are vegetables, rice husk, wood, cellulose, fibers and as well as waste-papers. This generates a large amount of wastewater. The poisonous effects on the biota are exhibited by the dark color of the waste paper and it obstructs the photosynthetic process by decreasing the sunlight (Swamy et al., 2011). Paper and pulp factories, notwithstanding being air polluters, produce a lot of inorganic contaminations, for example, sulfides, drying alcohols, and natural toxins including cellulose filaments, bark, wood sugars, and organic acids (PrintWeek India, 2018).

\section{Leather industry}

The Leather business in India represents around $12.9 \%$ of the world's leather manufacture of stows away/skins and handles a hearty yearly creation of around 3 billion square feet of leather. The nation represents $9 \%$ of the world's footwear manufacturer. The industry is known for its reliability in high trading earnings and it is among the chief ten overseas exchange earners for the nation. India has a bounty of crude materials with access to $20 \%$ of the world's cows and buffalo and $11 \%$ of the world's population of goats and sheep. The Leather business is an employment serving industry giving employment to in excess of 4 million individuals, generally from the weaker sections of the general public. Female engagement is leading in the leather items industry with about $30 \%$ portions. The Leather business in India has probably the most youthful workforce with $55 \%$ of the workforce underneath 35 years old. The Leather business tends to create 250 employments for each 0.2 million dollar venture (Invest India, 2019d). The tanneries generate a lot of salts, solids, chromium, sulfides, alkalinity, lime and so on., all of which have to be discarded in water bodies, which is the main cause of contamination of water bodies. The tannery waste is renowned by its odor, strong color, high biological oxygen demand (BOD), high chemical oxygen demand (COD), high total dissolved solids (TDS), high total suspended solids (TSS) and high pH. 


\section{Rubber and plastic industries}

The plastics business in India has developed and enhanced altogether since its initiation in 1957. The Indian plastics industry showcase has now developed to get one of the main segments in the nation's economy, comprising of more than 30,000 firms and engaging in excess of 4 million individuals. India is one of the world's top exporters of plastics items worldwide. The plastics industry produces and exports an assortment of crude materials, overlays, electronic accessories, therapeutic products, and consumer goods. These plastic items are sent out to in excess of 150 nations, chiefly in Africa, Europe and Asia (BizVibe, 2019). The plastics industry in India additionally gives plastic materials to a few different enterprises like the car, shopper bundling, and electronic gadgets manufacturers.

In the course of the most recent couple of decades, the interest for and use of plastics in numerous industries have expanded immensely. In the course of the recent 5 years, the Indian plastic industry has developed by $13 \%$ every year. A parallel growth level was expected to continue and the size of the industry was expected to reach around 25 billion dollars by 2016-17. Plastic industries produce organic matter and other hydrocarbons. Phenolic compounds pollute water and are results from industries like oil refineries, petrochemicals, leather and textile manufacturing, rubber, pesticides, pharmaceuticals, plastic and insecticide manufacturing (Srivastava et al., 2006).

\section{Metal industries}

The Indian metal industry is categorized into 2 primary divisions - the iron-based and non-ironbased metal ventures. The iron-based section incorporates the assembling of 3 various types of steel, for example, carbon steel, ferrochrome steel, and hardened steel. The non-iron-based class incorporates the making of copper, metal, tin, zinc, lead, manganese and aluminum. In the Indian metals industry, the primary tasks of the industries are mining of minerals, refining of the ores, alloying, casting, sheet, and folding into foils. India essential metals industry experienced vast changes during the 90 s with the beginning of the progression and open market strategies. With the new structure and sources of ventures, the foundation relating to the businesses was modified. Increasingly proficient and mechanically propelled strategies improved the production practices and thusly the yield of the industry expanded alongside the quality of the items. Fundamental metals industry of India is growing up with the inventive skills as it is helping the product market to amplify. A portion of the famous strategies utilized for the manufacturing of metals is open hearth, oxygen incinerators, blast furnaces, electric arc boilers, and so on (MOI, 2015). Steel industries produce excess water from the positioning of coal, vent (fireplace), washing of blast boiler, gases, and others. These waste be likely to be acidic and contain cyanogens, phenols, coke, metal, soluble bases, limestone, oils, and fine suspended solids. Metal 
enterprises associated with formulating of chromium, lead, nickel, zinc, silver, cadmium, copper, etc., additionally create acids, antacid cleaners and oil.

\section{Petroleum and oil industry}

India is the fourth biggest merchant of liquefied petroleum gas (LNG). India expended 213.2 MMT petroleum-based commodities and 60,747 MMSCM natural gas. The import reliance of unrefined oil and LNG during 2018 was $82.59 \%$ and $45.89 \%$ individually. During 2018 with a growth of $27 \%$ over 88 billion dollars during 2017 - 18, and $23.42 \%$ of all-out gross import of the country, the petroleum import bill was 112 billion dollars. India's anticipated oil demand is going to raise at cumulative average growth rate (CAGR) of $4 \%$ during 2016 - 2030 in contradiction of the world average of $1 \%$, however, the anticipated oil request will be far lower when compared with the US and China (Invest India, 2019b).

Petroleum products pollute water at each stage of their manufacturing, storing and transportation. They produce pollutants like oil spillage and saline water. The main causes of water pollution with phenolic mixtures are manufacturing like petrochemicals, oil refineries, textile and leather manufacturing, plastic, rubber, pharmaceuticals, pesticides, and insecticides (Srivastava et al., 2006). The release of phenolic wastes conveys a carbolic odor to water systems and cause a poisonous effect on plants, aquatic life and humans. Tumor formation, cancer and mutation are some of the side effects accelerated by them.

\section{Mining industry}

India holds a reasonable benefit in the cost of making and conversion costs in alumina and steel. Its tactical position empowers profitable exports to develop as well as the fast-developing Asian markets. India produces 95 minerals-4 fuel-related minerals, 23 non-metallic minerals, 10 metallic minerals, 3 nuclear minerals and 55 minor minerals (counting building and different minerals). The rise in infrastructure expansion and automotive manufacture is driving progress in the segment. Power and cement enterprises are likewise supporting growth in the metals and mining region. India is the third biggest manufacturer of coal. Coal production in the nation rose at 688.8 million tons in FY18. It remained at 576.00 million tons from April 2018 to March 2019. India ranks fourth in iron ore manufacturing worldwide. Manufactured iron ore was 210 million tons in FY18. India has around 8 percent of the world's stores of iron metal. India turned into the world's second-biggest unrefined steel maker in 2018 with yield 106.5 million tons. As per the Ministry of Mines, India has the seventh biggest bauxite assets- nearly 2,908.85 million tons in FY17. Aluminum manufacture was 1.33 million metric tons during April-August 2018 and is anticipated to become 3.33 million tons in FY20 (IBEF, 2019). The contagions of mining are chlorides, ferric hydroxide, sulphuric corrosive, ferrous sulfate, hydrogen sulfide, suspended solids, chlorides, and others. 


\section{Current status of ground and surface water pollution by IIHs}

Previous reports have concluded that effluent discharges from $\mathrm{IIH}$ or individual industry has an extreme impact on ground and surface water quality. Out of them, Tariq et al. (2006) analyzed the characteristics of industrial effluents and their influences on quality of underground water and concluded that the characteristics of effluents were different according to the industry. The $\mathrm{pH}$ of effluent from aluminum industry was beyond and of the remaining industries was within the permissible limit whereas total suspended solids (TSS) of effluent of Pepsi industry was within and of the remaining industries were above the permissible limits compared with NEQS (National Environmental Quality Standards). In almost all of the effluents, the biochemical oxygen demand (BOD) was exceeding the permissible limit. Heavy metals like cadmium, chromium, copper, iron and zinc were in the permissible limits in all but manganese, nickel and lead were beyond the permissible bounds in some effluents. Shankar et al. (2008) studied the impact of industrialization on groundwater quality - a case study of Peenya industrial area, Bangalore, India and revealed that almost $77 \%$ of the samples are polluted and unhealthy for domestic use. The results visibly show that the groundwater is getting polluted terrifyingly due to quick industrialization. The inquiries along with the consultations held with the official health centers and local public of the region, evidently point out to the severe pollution of the groundwater in the locality of the industries.

Tariq et al. (2010) observed the dispersal and distribution of some metals in effluents from tannery and found that the groundwater and soil systems in the locality of these tanneries were contaminated by chromium $(\mathrm{Cr})$, cobalt $(\mathrm{Co})$, cadmium $(\mathrm{Cd})$, nickel $(\mathrm{Ni})$, lead $(\mathrm{Pb})$, manganese $(\mathrm{Mn})$, sodium $(\mathrm{Na})$, potassium $(\mathrm{K})$, calcium $(\mathrm{Ca})$ and iron $(\mathrm{Fe})$, to the amount that they pose a hazard to the surroundings. These metals and chemicals initiate from many procedures such as tanning/retaining, liming/delimbing and finishing steps of leather manufacture. The greater chromium levels were mainly dangerous for human health. Additionally, raised sodium (Na) levels could turn the groundwater into the saline water, thus disturbing its appropriate use for commercial, irrigation, and drinking purposes. Brindha and Elango (2012) determined the effect of tanning industries on groundwater quality near a metropolitan city in India and concluded that $\mathrm{Na}-\mathrm{Cl}$ was the prevailing groundwater type. A big proportion of groundwater samples collected from this study site is of saline water type based on the concentration of total dissolved solids (TDS). From all the samples collected only $28 \%$ samples were desirable for drinking purpose and thus a larger portion of groundwater is not appropriate for domestic use.

A large share of groundwater of this zone is hard water. In $86 \%$ of the groundwater samples chromium was exceeding beyond the permissible limit. The composition of groundwater was alike to that of the treated effluent. Generally, the groundwater in this zone had been 
concentrated with the hazardous chemicals that were utilized during the tanning procedure, which specify the influence of effluent discharged by the tanning activities. Singh et al. (2013) observed the effect of polluted surface water on groundwater and revealed that the quality of the surface water at different sections of Budha Nullah had been decreased as the stream headways through the city. Human settlements and untreated wastes from the industries are found to be the main source for degradation of the water quality in Ludhiana. The surface water investigation of Budha Nullah exposed high values of total dissolved solids (TDS) up to $1642 \mathrm{mg} / \mathrm{L}$, chlorides ranged to $400 \mathrm{mg} / \mathrm{L}$, chemical oxygen demand (COD) reached up to $448 \mathrm{mg} / \mathrm{L}$, biochemical oxygen demand (BOD) was fluctuating between $52-195 \mathrm{mg} / \mathrm{L}$, most potable number (MPN) varied from $240+$ upto $2400+/ 100 \mathrm{ml}$, heavy metal like Chromium $(\mathrm{Cr})$ in the Budha Nullah was $0.084 \mathrm{mg} / \mathrm{L}$, Iron (Fe) $0.913 \mathrm{mg} / \mathrm{L}$, Manganese (Mn) $0.095 \mathrm{mg} / \mathrm{L}$ and Nickel (Ni) $0.222 \mathrm{mg} / \mathrm{L}$. According to the water quality standards specified by Central Pollution Control Board (CPCB), the water quality of Budha Nullah came under E class of water which was not appropriate for drinking purpose, bathing, irrigation and industrial cooling, propagation of wildlife and fisheries. Bhadra et al. (2013) studied the impact of industrial effluents on groundwater around Pali city, Rajasthan and revealed the impact of contaminants on the croplands. The very red/black coloured industrial effluent was carried by Bandi River, which is alkaline and rich in organics and other soluble salts. With growing concentration of total dissolved solids (TDS), chloride, sulphate etc., the salinity of water increased. Up to a distance of 50 kilometers in the downstream direction, the current of effluent of Bandi River had impacted the quality of groundwater in wells from Pali city to Nerda dam. Sodium (Na), total dissolved solids (TDS), chloride ( $\mathrm{Cl}$ ) and sulphate $\left(\mathrm{SO}_{4}{ }^{2-}\right)$ were very high in groundwater. It had been incidental that extreme damage to the croplands had taken place between 1979 and 2005, on equating the quality factors of different sources. Nirgude et al. (2015) performed the physico-chemical analysis of some industrial effluents from Vapi industrial area, Gujarat, India and concluded that total dissolved solids (TDS), electrical conductivity (EC), chlorides sulphates $\left(\mathrm{SO}_{4}{ }^{2}\right)$, chemical oxygen demand (COD), biochemical oxygen demand (BOD), sodium ( $\mathrm{Na}$ ) and calcium (Ca) were very high in concentration compared to the standards set by WHO. Additionally, they also recommended that such effluent must not be discharged in to the nearby water bodies or soil without any treatment. Such effluents were unhealthy for irrigation purpose. The elevated level contamination of the industrial effluents causes natural issues which would influence plant, animal and human life. Copaciu et al. (2015) did the assessment of industrial effluents quality and their possible impact on surface water and found that the analyzed physicochemical parameters were diverse significantly with the source of effluent.

The assessment showed a seasonal difference for some parameters. The quality of the assessed effluents was below the limits set by Romanian and UE legislation in some cases. Some parameters exceeded the limits set by legislation but parameters like the total dissolved solids 
(TDS), chloride $\left(\mathrm{Cl}^{-}\right)$, sulphate $\left(\mathrm{SO}_{4}{ }^{2}\right)$ and detergents content of the effluents were found within the permissible limits for surface water discharge. Chowdhury et al. (2015) performed the characterization of the effluents from leather processing industries and found extremely high values of total suspended solids (TSS), total dissolved solids (TDS), total solids (TS), biochemical oxygen demand(BOD), chemical oxygen demand (COD), sulphate $\left(\mathrm{SO}_{4}{ }^{2-}\right)$, sodium (Na), chromium $(\mathrm{Cr})$, arsenic $(\mathrm{As})$, cadmium $(\mathrm{Cd})$ and lead $(\mathrm{Pb})$ in the effluents sampled from various manufacturing phases in the three different selected leather industries. The values were far exceeding the permissible limits. The results also indicated that the main physico-chemical parameters of all complex effluents at three monitoring points surpassed the standard discarding limits. The order of concentration of metals in the sludge from high to low was chromium $(\mathrm{Cr})$, sodium $(\mathrm{Na})$, calcium $\mathrm{Ca}$, sulphur $(\mathrm{S})$, manganese $(\mathrm{Mg})$, copper $(\mathrm{Cu})$, zinc $(\mathrm{Zn})$, lead $(\mathrm{Pb})$, arsenic (As), cadmium (Cd). Noukeu et al. (2016) analyzed characterization of effluent from food processing industries and did stillage treatment trial with Eichhornia crassipes (Mart.) and Panicum maximum (Jacq.). The investigation revealed that effluents from food processing industries had enormously great levels of chemical oxygen demand (COD), total suspended solids (TSS), biochemical oxygen demand (BOD), phosphate $\left(\mathrm{PO}_{4}{ }^{{ }^{-}}\right)$and nitrate $\left(\mathrm{NO}_{3}{ }^{-}\right)$. These values were mostly exceeding the limits set by WHO They proposed that without treatment, those effluents were not appropriate to be discharged into natural environments. Their biological treatment could be done as they had high values of organic materials.

Afzal et al. (2018) performed characterization of industrial effluents and groundwater of Hattar industrial estate, Haripur and concluded that the effluents were highly contaminated with heavy metals, humiliating the groundwater quality and making it unsuited for irrigation. Additionally, the groundwater in the locality of industrial estate was hugely contaminated by industrial effluents and considered as inappropriate for consumption. Internationally, Santucci et al. (2018) studied industrial waste as a source of surface and groundwater pollution in the Río de la Plata coastal plain (Argentina) and revealed that environmental alterations due to heavily polluted soils from industrial activity caused in chemical alterations in surface water and groundwater. The penetration of waste resulting from the industrial area is the basis of the increased concentrations of sulphates $\left(\mathrm{SO}^{2-}\right)$ in water. According to the results found in this study, the sulfuric acid $\left(\mathrm{H}_{2} \mathrm{SO}_{4}\right)$ industry waste uncontrolled half a century ago were still a source of soil and groundwater pollution and they posture a hazard to human wellbeing.

Ahsan et al. (2019) studied chemical and physicochemical characterization of effluents from the tanning and textile industries in Bangladesh and found that tanneries and textile dyeing in the study area discharge effluents comprising numerous poisonous contaminants at a noteworthy level. Effluent samples disclosed high concentrations of total suspended solids (TSS), electrical conductivity (EC) and total dissolved solids (TDS) which surpassed the Bangladesh standard 
limits. Despite the fact that most heavy metal concentrations were inside the point of confinement with the exception of chromium $(\mathrm{Cr})$ concentration in the tannery effluents. Textile dyeing effluents had elevated level of $\mathrm{NO}^{3-}, \mathrm{NO}^{2-}$ and $\mathrm{pH}$ though tannery effluents had lower dissolved oxygen (DO) and $\mathrm{pH}$ values, and higher biochemical oxygen demand (BOD), chloride $\left(\mathrm{Cl}^{-}\right)$, sulphate $\left(\mathrm{SO}_{4}{ }^{2-}\right)$ and Chromium $(\mathrm{Cr})$ concentrations than the standard limits. Now a days wastewaters from IIHs are being effectively treated by biological processes including phytoremediation and bioenergy production (Kumar et al., 2019a; Kumar et al., 2020)

\section{Conclusion}

From the above reports, it is concluded that clustered industrialization is responsible for environmental pollution and consequential human health hazards, it is necessary to curb the worst excesses committed by IIHs, by way of legal restrictions on the processes and the use of its wastewater. Therefore, in a developing country like India, with alarming conditions of environmental pollution, lack of awareness of its causes and consequences, if unattended, mere enactments and amendments of legislation are not enough. Water and human health are correlated wherein one affects the other, and the magnitude of the problem is such that its solution invites an integrated approach. Thus, proper treatment and disposal of IIH wastewater should be done to mitigate its environmental impacts.

\section{References}

Afzal, M.S., Ashraf, A. and Nabeel, M. (2018). Characterization of industrial effluents and groundwater of Hattar industrial estate, Haripur. Advances in Agriculture and Environmental Science, 1(2): 70-77.

Agarwal, V.K. (2005). Environmental laws in India: challenges for enforcement. Bulletin of the National Institute of Ecology, 15: 227-238.

Ahsan, M.A., Satter, F., Siddique, M.A.B., Akbor, M.A., Ahmed, S., Shajahan, M. and Khan, R. (2019). Chemical and physicochemical characterization of effluents from the tanning and textile industries in Bangladesh with multivariate statistical approach. Environmental Monitoring and Assessment, 191(9): 575.

Allan, J.D. (1995): Stream ecology of running waters. Kluwer; Academic publishers, London, UK.

Bhadra, B.K., Pathak, S. and Sharma, J.R. (2013). Impact of industrial effluents on groundwater around Pali City, Rajasthan using field and satellite data. Journal of the Geological Society of India, 82(6): 675-691.

Birley, M. and Lock, K., (1999). A review of health impacts of peri-urban natural resource development. International Health Impact Assessment Research Group, University School of Medicine.

BizVibe (2019). Indian Plastics Industry: 2018 Overview and Insights. Retrieved on 5 January 2020 from https://www.bizvibe.com/blog/plastics-leather-and-rubber/indian-plastics-industry-overview/

Brindha, K. and Elango, L. (2012). Impact of tanning industries on groundwater quality near a metropolitan city in India. Water Resources Management, 26(6): 1747-1761.

British Geological Survey (2008). The impact of industrial activity. In: Groundwater Information Sheet, NERC, pp. 1-6. Retrieved on 10 September 2019 from https:// washmatters.wateraid.org/publications/impact-of-industrial-activity-on- 
groundwater-quality-2008.

Chennakrishnan, C., Stephren, A., Manju, T. and Raveen, R. (2008): Water Quality status of three vulnerable freshwater Lakes of Suburban Chennai, India.

Chillers, J. and A, Henrik. (1996). Effect of contaminated water. Global Water Hazards, 25: 25-27.

Chowdhury, M., Mostafa, M.G., Biswas, T.K., Mandal, A. and Saha, A.K. (2015). Characterization of the effluents from leather processing industries. Environmental Processes, 2(1): 173-187.

Chutter, F.M. (1998): Research on the rapid Biological Assessment of Water Quality Impacts in streams and Rivers.

Copaciu, F, Roba, C., Opriș, O., Bunea, A. and Mireșan, V. (2015). Assessment of Industrial Effluents Quality and their Possible Impact on Surface Water. Bulletin of University of Agricultural Sciences and Veterinary Medicine Cluj-Napoca. Animal Science and Biotechnologies, 72(2): 131-141.

Edokpayi, J.N., Odiyo, J.O., Olasoji, S.O. (2014). Assessment of heavy metal contamination of Dzindi River, in Limpopo Province, South Africa. International Journal of Natural Science Research, 2: 185-194.

Faure, M.G. (1995). Enforcement issues for environmental legislation in developing countries. (Internet). Available online: http://archive.unu.edu/hq/library/Collection/PDF_ files/INTECH/INTECHwp19.pdf [Accessed 2015/8/19].

Feris, L.A. (2006) Compliance notices - a new tool in environmental enforcement. Potchefstroom Electronic Law Journal, 9(3): 5370 .

Gregory, L.R. (2011). First Preparatory Meeting of the World Congress on Justice, Governance and Law for Environmental Sustainability. Kuala Lumpur, Malaysia. [Internet].; pp. 1-30. Available online: http://www.unep.org/delc/ Portals/24151/FormatedGapsEL. pdf [Accessed 2015/8/19].

IBEF (2019). India Brand Equity Foundation: Metals \& Mining Industry in India. Retrieved on 10 December 2019 from https://www.ibef.org/industry/metals-and-mining.aspx

Invest India (2019a). Snapshot: India - Knitting the future: India is among the world's largest producers of Textiles and Apparel. Retrieved on 10 December 2019 from https://www.investindia.gov.in/sector/textiles-apparel.

Invest India (2019b). Snapshot: World's fastest-growing energy market: India is the 3rd largest energy and oil consumer in the world after China and the US. Retrieved on 5 January 2020 from https://www.investindia.gov.in/sector/oil-gas.

Invest India (2019c). Snapshot: World's chemical nucleus: Retrieved on 5 January 2020 from https://www.investindia.gov.in/sector/chemicals.

Invest India (2019d). Snapshot: World's tannery: Retrieved on 10 December 2019 from https://www.investindia.gov.in/ sector/leather.

Invest India (2020). Snapshot: Food processing - A sunrise sector: Retrieved on 5 January 2020 from https://www.investindia.gov.in/sector/food-processing.

Kumar, V., Chauhan, R.K., Srivastava, S., Singh, J. and Kumar, P. (2018). Contamination, enrichment and translocation of heavy metals in certain leafy vegetables grown in composite effluent irrigated soil. Archives of Agriculture and Environmental Science, 3(3), 252-260.

Kumar, V., Kumar, P., Singh, J. and Kumar, P. (2019a). Potential of water fern (Azolla pinnata R. Br.) in phytoremediation of integrated industrial effluent of SIIDCUL, Haridwar, India: removal of physicochemical and heavy metal pollutants. International Journal of Phytoremediation, 1-12. https:// doi.org/10.1080/15226514.2019.1667950

Kumar, V., Thakur, R.K. and Kumar, P. (2019b). Assessment of heavy metals uptake by cauliflower (Brassica oleracea var. botrytis) grown in integrated industrial effluent irrigated soils: A prediction modeling study. Scientia Horticulturae, 257, 108682. https://doi.org/10.1016/j.scienta.2019.108682

Kumar, V., Kumar, P., Kumar, P., and Singh, J. (2020). Anaerobic digestion of Azolla pinnata biomass grown in integrated industrial effluent for enhanced biogas production and COD reduction: Optimization and kinetics studies. Environmental Technology \& Innovation, 100627. https:/ / doi.org/10.1016/j.eti.2020.100627

MOI (2015). Maps of India: Metal Industry in India. Retrieved on 10 December 2019 from https://business.mapsofindia.com/ india-industry/basic-metals.html

Mathuthu, A.S., Mwanga, K and Simoro, A. (1997): Impact Assessment of Industrial and Sewage Effluents on Water Quality 
of receiving Marimba River in Harare.

Mdamo, A. (2001): Accumulation of Nutrients and Heavy Metals in plants at Kagondo natural Wetland (Draft Paper).

Morris, B.L., Lawrence, AR., Chilton, PJ, Adams, B, Calow, R and Klinck, BA. (2003). Groundwater and its susceptibility to degradation: A global assessment of the problems and options for management. Early Warning and Assessment Report Series, RS, 03-3. United Nations Environment Programme, Nairobi, Kenya.

Munter, R. (2003). Industrial wastewater characteristics. The Baltic University Programme (BUP), Sweden, pp.185-194.)

Noukeu, N.A., Gouado, I., Priso, R.J., Ndongo, D., Taffouo, V.D., Dibong, S.D. and Ekodeck, G.E. (2016). Characterization of effluent from food processing industries and stillage treatment trial with Eichhornia crassipes (Mart.) and Panicum maximum (Jacq.). Water Resources and Industry, 16: 1-18.

Pandey, K. (2019). Grossly polluting industries more than doubled in 8 years: SOE in Figures. Down to earth. Retrieved from https://www.downtoearth.org.in/news/pollution/grossly-polluting-industries-more-than-doubled-in-8-years-soe-infigures-64962 on 28 November 2019.

PrintWeek India (2018). Indian paper industry moving out of the woods. Retrieved on 5 December 2019 from https://www.printweek.in/news/indian-paper-industry-moving-woods-29617.

Ramjeawon, T. (2000). Cleaner production in Mauritiancane - sugarfactories. Journal of Cleaner Production, 8503-510.

Santucci, L., Carol, E. and Tanjal, C. (2018). Industrial waste as a source of surface and groundwater pollution for more than half a century in a sector of the Río de la Plata coastal plain (Argentina). Chemosphere, 206: 727-735.

Shankar, B.S., Balasubramanya, N. and Reddy, M.M. (2008). Impact of industrialization on groundwater quality-a case study of Peenya industrial area, Bangalore, India. Environmental Monitoring and Assessment, 142(1-3): 263-268.

Singh, G., Singh, D.D. and Sharma, S.K. (2013). Effect of polluted surface water on groundwater: A case study of Budha Nullah. Journal of Mechanical and Civil Engineering, 1-8.

Srivastava, V.C., Swamy, M.M., Mall, I.D., Prasad, B., Mishra, I.M.: Adsorptive removal of phenol by bagasse fly ash and activated carbon. Colloids Surf. A: Physicochemical and Engineering Aspects, 272, 89- 104 (2006)

Swamy N.K., Singh P. and Sarethy I.P. (2011). Precipitation of phenols from paper industry waste paper using ferric chloride. Rasayan Journal Chemistry, 4(2): 452-456.

Tariq, M., Ali, M. and Shah, Z. (2006). Characteristics of industrial effluents and their possible impacts on quality of underground water. Soil Environment, 25(1): 64-69.

Tariq, S.R., Shaheen, N., Khalique, A. and Shah, M.H. (2010). Distribution, correlation, and source apportionment of selected metals in tannery effluents, related soils, and groundwater-a case study from Multan, Pakistan. Environmental Monitoring and Assessment, 166(1-4): 303-312.

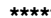

Cite this chapter as: Kumar, V., Kumar, P., Singh, J. and Kumar, P. (2020). Current status of water pollution by integrated industrial hubs (IIHs) in India. In: Environmental Degradation: Causes and Remediation Strategies, Volume 1, Eds. Kumar, V., Singh, J. and Kumar, P., pp. 104-119, https://doi.org/10.26832/aesa-2020-edcrs-08 